\title{
SOLAR AND ATLANTIC OCEAN INFLUENCE ON CLIMATE OF FENNOSCANDIA
}

\author{
Ogurtsov M.G. ${ }^{1,2}$, Jungner H. ${ }^{3}$ \\ ${ }^{1}$ Ioffe Physico-Technical Institute of RAS, St. Petersburg, Russia \\ ${ }^{2}$ Central Astronomical Observatory of RAS, St. Petersburg, Russia \\ ${ }^{3}$ University of Helsinki, Finland
}

\section{ВЛИЯНИЕ СОЛНЕЧНОЙ АКТИВНОСТИ И АТЛАНТИЧЕСКОГО ОКЕАНА НА КЛИМАТ ФЕННОСКАНДИИ}

\author{
Огурцов М.Г. ${ }^{1,2}$, Юнгнер X. ${ }^{3}$ \\ ${ }^{1}$ ФТИ им. А.Ф. Иоффе РАН, г. Санкт-Петербург, Россия \\ ${ }^{2}$ ГАО РАН, г. Санкт-Петербург, Россия \\ ${ }^{3}$ Университет г. Хельсинки, Финляндия
}

\begin{abstract}
Восемь прямых и косвенных индексов: (а) летнего климата в Фенноскандии, (б) температуры поверхности океана в северной Атлантике, (в) солнечной активности, исследованы на временном интервале, охватывающем последние 3-4 столетия. Солнечно-климатические коррелящии были изучены на различных временных шкалах. Новые свидетельства существования связи между активностью Солнца, температурой воды в северной Атлантике и летней температурой в северной Фенноскандии были получены с использованием новейших палеоданных. Показано, что эта взаимосвязь комплексная, нестабильная и её характер зависит от временной шкальл. Свидетельств влияния солнечной активности на климат восточной Фенноскандии не обнаружено.
\end{abstract}

\section{DOI: 10.31725/0552-5829-2019-309-312}

\section{Introduction}

Fennoscandia (particularly, its northern part) is a geographic region appropriate for examination of possible solar-climate connection. Actually, this domain is located at high latitudes i.e. (a) in a zone of a low geomagnetic rigidity cutoff where penetration of energetic cosmic ray particles into atmosphere is facilitated and (b) close to the area, affected by stratospheric polar vortex, which likely play important role in the formation of solar activity (SA) effects on the atmospheric circulation [1]. Potential connection between the climate of Northern Fennoscandia (NF) and activity of the Sun has been studied in a number of works [2-5]. The present work is aimed at examination of a link between (a) SA, (b) climate of North Fennoscandia, (c) climate of East Fennoscandia, (d) variations of SST at North Atlantic during the last 300-400 years. The performed analysis included study of correlation:

(a) between the raw records (ES correlation);

(b) between records filtered over a century-long scale (periods 53-133), corresponding to the Gleissberg solar cycle (CS correlation);

(c) between records filtered over high-frequency scale (periods $<30$ years) corresponding to the Schwabe and Hale solar cycles (HFS correlation). 


\section{Data}

All the data sets used in analyses: (a) have annual resolution that allows to use them for search of short-term correlations, (b) cover 3-4 last centuries that allows to use them for search of century-long correlations, (c) cover the sector of the Northern Hemisphere of interest for us. They are:

(a) A record of carbon stable isotope ratios ${ }^{13} \mathrm{C} /{ }^{12} \mathrm{C}\left(\delta^{13} \mathrm{C}\right)$ measured from tree rings from Northern Fennoscandia (NF) and covering the time interval 1600-2002 AD [6].

(b) A record of carbon stable isotope ratios ${ }^{13} \mathrm{C} /{ }^{12} \mathrm{C}$ measured from tree rings from Eastern Fennoscandia (EF) and covering time interval 1600-2002 AD [6].

(c) A reconstructed record of SST in the North Atlantic $\left(0-70^{\circ} \mathrm{N}\right)$ obtained by Gray et al. [7] (SST-Gray) using twelve tree-ring series;

(d) A reconstructed record of AMO obtained by Mann et al. [8] (AMOMann) using more than 1138 time series (tree-rings, ice-core, corals, speleothems etc.);

(e) A reconstructed record of July and August average daily sunshine hours (NFSunsh) based on the stable carbon isotope ratios ${ }^{13} \mathrm{C} /{ }^{12} \mathrm{C}$ measured from pine tree rings from Northern Fennoscandia [9].

(f) Instrumental sunspot number $S_{\mathrm{N}}$ during AD 1700-1995 [10].

(g) Solar modulation potential $\Phi_{\text {NGRIP }}(\mathrm{MV})$ calculated by Ogurtsov [11] using data on flux of ${ }^{10} \mathrm{Be}$ measured from an ice core from North Greenland (NGRIP core) by Berggren et al. (2009);

(h) Solar modulation potential $\Phi_{\text {Dye3 }}(\mathrm{MV})$ calculated by Ogurtsov [11] using data on flux of ${ }^{10}$ Be measured from an ice core from South Greenland (Dyes core) by Beer et al. (1994).

\section{Results}

Results of correlation analysis, performed over AD 1716-1985 are generalized in Tables 1 . In the Table we use small letters E, H, C if the corresponding

Table 3. Correlations over AD 1716-1985.

\begin{tabular}{|l|l|l|l|l|l|l|l|l|}
\hline & $\begin{array}{l}\Phi \\
(\text { NGRIP) }\end{array}$ & $\begin{array}{l}\Phi \\
(\text { Dye-3) }\end{array}$ & $\begin{array}{l}\text { SST } \\
(\text { Gray })\end{array}$ & $\begin{array}{l}\text { AMO } \\
(\text { Mann })\end{array}$ & $\begin{array}{l}\delta^{13} \mathrm{C} \\
(\mathrm{NF})\end{array}$ & $\begin{array}{l}\delta^{13} \mathrm{C} \\
(\mathrm{EF})\end{array}$ & $\mathrm{S}_{\mathrm{N}}$ & NFSunsh \\
\hline$\Phi$ (NGRIP) & & EH & EH & EC & EHC & & EHC & C \\
\hline$\Phi$ (Dye-3) & & & H & & & & EHC & \\
\hline SST (Gray) & & & & EHC & EH & EHC & E & EHC \\
\hline $\begin{array}{l}\text { AMO } \\
\text { (Mann) }\end{array}$ & & & & & C & & & EC \\
\hline$\delta^{13} \mathrm{C}(\mathrm{NF})$ & & & & & & EH & EH & EHC \\
\hline$\delta^{13} \mathrm{C}(\mathrm{EF})$ & & & & & & & & EH \\
\hline $\mathrm{S}_{\mathrm{N}}$ & & & & & & & & H \\
\hline NFSunsh & & & & & & & & \\
\hline
\end{tabular}

Correlation analysis, performed over AD 1600-1985 brought similar results. 
ES, HFS and CS correlations are significant at a 0.90-0.95 confidence level (c.l.). If the significance exceeds 0.95 c.l. we use large letters. The significance of correlation between records (both raw and filtered) was estimated using a numerical random-phase test, which included a number of Monte Carlo simulations.

\section{Conclusion}

Analyses of the solar and climatic records showed that:

1) Solar activity actually influences climate of Northern Fennoscandia during the last 3-4 centuries. Character of solar-climatic link, however, varies with time. In a few cases effect weakens when we use novel and, likely, improved solar indexes (SN, $\left.\Phi_{\mathrm{NGRIP}}, \Phi_{\text {Dye3 }}\right)$.

2) Solar activity actually influences sea surface temperature at North Atlantic during the last 3-4 centuries. Character of this link also is not stable.

3) Solar-climatic link over the Northern Fennoscandian region most probably is mediated by a number of processes in the system ocean-atmosphere.

4) Connection between activity of the Sun and climate at Fennoscandia has a regional-scale distribution.

The obtained results shows need of further efforts in solar paleoastrophysics and paleoclimatology.

\section{Acknowledgement}

The work was supported by RFBR grants 18-02-00583, 19-02-00088.

\section{References}

1. Veretenenko, S., Ogurtsov, M. 2014. Stratospheric polar vortex as a possible reason for temporal variations of solar activity and galactic cosmic ray effects on the lower atmosphere circulation // Adv. Space Res. 54, 2467-2477.

2. Ogurtsov, M.G., Sonninen, E., Hilasvuori, E., et al. 2011. Variations in tree ring stable isotope records from northern Finland and their possible connection to solar activity // J. Atmos. Terr. Phys. 73, 383-387.

3. Ogurtsov, M., Lindholm, M., Jalkanen, R., Veretenenko, S.V. 2013. New evidence of solar variation in temperature proxies from Northern Fennoscandia // Adv. Space Res. 52(9), 1647-1654.

4. Ogurtsov, M., Lindholm, M., Jalkanen, R., Veretenenko, S.V. 2017. North Atlantic sea surface temperature, solar activity and the climate of Northern Fennoscandia. Adv. Space Res. 59(4), 980-986.

5. Helama, S., Fauria, M.M., Mielikäinen, K., et al. 2010. Sub-Milankovitch solar forcing of past climates: Mid and late Holocene perspectives // Geol. Soc. Am. Bull. 122, 1981-1988.

6. Hilasvuori, E., Berninger, F., Sonninen, E., et al. 2009. Stability of climate signal in carbon and oxygen isotope records and ring width from Scots pine (Pinus sylvestris L.) in Finland. // J. Quat. Sci. 24, 469-480.

7. Gray, S., Graumlich, L., Betancourt, J., Pederson, G. 2004. A tree-ring based reconstruction of the Atlantic Multidecadal Oscillation since 1567 AD // Geophys. Res. Lett. 31, L12205, doi:10.1029/2004GL019932. 
8. Mann, M.E., Zhang, Z., Rutherford, S. et al. 2009. Global signatures and dynamical origins of the Little Ice Age and Medieval climate anomaly // Science 326, 1256-1270.

9. Gagen, M., Zorita, E., McCarroll, D., et al. 2011. Cloud response to summer temperatures in Fennoscandia over the last thousand years // Geophys. Res. Lett., 38, L05701, doi:10.1029/2010GL046216.

10. SILSO, World Data Center - Sunspot Number and Long-term Solar Observations, Royal Observatory of Belgium, on-line Sunspot Number catalogue: http://www.sidc.be/SILSO

11. Ogurtsov, M.G. 2018. Solar activity during the Maunder Minimum: comparison with the Dalton Minimum // Astron. Lett. 44 (4), 278-288.

12. Berggren, A.-M., Beer, J., Possnert, G. et al. 2009. A 600 -year annual ${ }^{10}$ Be record from the NGRIP ice core, Greenland // Geophys. Res. Lett. 36, L11801, doi:10.1029/2009GL038004.

13. Beer, J., Baumhartner, S., Dittrich-Hannen, B. et al. 1994. Solar variability traced by cosmogenic isotopes. The Sun as a variable star. (ed. J.M. Pap). Cambridge University Press, New York. P. 291-300. 